kota lama semarang menuju status pusaka dunia unesco

\title{
KOTA LAMA SEMARANG MENUJU STATUS PUSAKA DUNIA UNESCO: APA ITU STATUS WORLD HERITAGE?
}

\author{
Bintang Noor Prabowo*) Bangun I.R. Harsritanto**) \\ *) Program Studi Gambar Arsitektur, Sekolah Vokasi, Universitas Diponegoro \\ **) Program Studi Teknik Arsitektur, Fakultas Teknik, Universitas Diponegoro
}

\begin{abstract}
Kawasan Kota Lama sempat mengalami kondisi stagnan, bahkan cenderung menurun kualitas lingkungannya, di periode tahun 1980 hingga 1990-an. Jangankan di malam hari, bahkan di siang hari pun, kawasan ini seperti kawasan kota mati, dengan dominasi aktifitas pergudangan dan bangunan-bangunan yang dibiarkan kosong dan mangkrak. Penelitian ini dilakukan dengan metode studi literatur warisan dunia dan studi kasus kota lama secara analisa deskripsi terhadap temuan observasi lapangan. Penelitian ini bertujuan untuk mengkaji sasaran kotalama semarang dalam kriteria pusaka dunia. Hasil dari penelitian ini adalah kriteria yang realistis bagi kotalama Semarang sebagai pusaka hidup dunia.
\end{abstract}

Keywords: kotalama semarang; pusaka; unesco; kriteria; studi literatur

\section{Pendahuluan}

Sejak berbenah pada akhir tahun 1990-an, Kawasan Kota Lama semarang yang sering kali disebut sebagai Little Netherland atau Belanda Kecil perlahan tapi pasti mulai memperoleh perhatian dari publik dan pemerintah (Hendro, Eko Punto, 2015).

Kawasan Kota Lama sempat mengalami kondisi stagnan, bahkan cenderung menurun kualitas lingkungannya, di periode tahun 1980 hingga 1990-an. Jangankan di malam hari, bahkan di siang hari pun, kawasan ini seperti kawasan kota mati, dengan dominasi aktifitas pergudangan dan bangunan-bangunan yang dibiarkan kosong dan mangkrak.

Di beberapa bagian kawasannya, sanitasi lingkungannya sangat buruk. Saluran-saluran yang mampet dan banjir rob menggenangi sebagian kawasan hampir sepanjang tahun. Bangunan-bangunan yang ada mengalami proses pelapukan karena tidak dirawat. Sebagian diantaranya bahkan rubuh (atau dirubuhkan) dan menyisakan puing-puing. Gang-gang dan koridor jalan terlihat suram dan menyeramkan. Faktor keamanan, (setidaknya dalam persepsi pelintas), juga menjadi isu utama yang turut berperan membuat kawasan Kota Lama menjadi semakin sepi dan kurang diminati untuk sekedar dikunjungi (BAPPEDA, 2011)

Sejak dikeluarkannya SK Walikota Semarang Nomor 646/50/1992 tentang Konservasi BangunanBangunan Kuno/Bersejarah di Wilayah Kotamadya Daerah Tingkat II Semarang, yang sejatinya merupakan peraturan turunan dari UU. No 5 tahun 1992 tentang Benda Cagar Budaya, Semarang memulai langkah strategisnya untuk melestarikan bangunan bersejarah dengan disusunnya daftar Bangunan Cagar Budaya. Dalam perkembangannya, undang-undang mengenai Benda Cagar Budaya disempurnakan lagi menjadi UU. No 11 tahun 2010 tentang Cagar Budaya.

Awalnya, hanya segelintir pemerhati dan pecinta cagar budaya yang menyadari potensi Kota lama Semarang. Komunitas fotografi dan budaya, jauh hari sebelum Little Netherland ini menjadi terkenal, sudah melirik banyak spot cantik, di sekitar kawasan Kota Lama. Sineas Nasional Hanung Bramantyo, misalnya, juga pernah menjadikan beberapa titik di kawasan Kota Lama Semarang sebagai lokasi pengambilan gambar dalam film Ayat-Ayat Cinta pada tahun 2004 (Grahadwiswara, Agastya, et al., 2014)

Perkembangan dari teknologi informasi dan merebaknya media sosial pada sekitar tahun 2010-an rupanya mempunyai peran yang signifikan dalam mengabarkan keberadaan permata yang belum sepenuhnya terpoles dan masih terpendam di dalam lumpur masa lalu itu.

Kekuatan sosial media harus diakui berperan besar dalam mempromosikan dan memviralkan potensi destinasi wisata di berbagai pelosok wilayah di seluruh Indonesia, termasuk di Kota Lama Semarang.

Kekayaan dan keragaman arsitektur di kawasan Kota Lama Semarang ini menjadikan sejumlah posting di media sosial menjadi viral dan mengundang rasa penasaran para wisatawan lokal maupun mancanegara. Akibatnya mudah ditebak, kunjungan wisatawan ke kawasan ini meningkat tajam dari tahun ke tahun, 
seiring dengan terus dilakukannya penataan di Little Netherland, berikut munculnya titik-titik pendukung pariwisata lainnya, baik dari pihak swasta maupun karena campur tangan pemerintah daerah dan pusat.

\section{Diskusi dan Hasil}

Mengingat segala potensi dan modal dasar yang dimilikinya, Kota Lama Semarang diprediksi akan menjadi kawasan yang hidup, baik secara sosial, ekonomi, maupun budaya, jauh melebihi Kawasan Malioboro di Jogjakarta. Dengan kafe-kafe, kantor, pusat perbelanjaan souvenir, serta pertunjukan budaya, dengan wisatawan dan pecinta budaya yang berlalulalang di sekitar kawasan yang nyaman, aman, tidak dilalui kendaraan bermotor, dan tersedia kantongkantong parkir dan fasilitas umum/sosial yang baik, artistik, dan memadai.

Saat ini, Kota Lama Semarang sedang menapaki jalannya untuk dapat diakui sebagai salah satu Pusaka Dunia, dengan mengajukan diri kepada komite World Heritage, suatu lembaga di bawah UNESCO, yang bertugas mendata dan memastikan kelestarian Pusaka Dunia.

Targetnya cukup ambisius, pada tahun 2020, Kota Lama semarang akan resmi masuk ke dalam daftar World Heritage.

Bahkan sekelas Kota Tua Jakarta (Oud Batavia) dengan perhatian dan pendanaan yang begitu besar, sudah berkali-kali diajukan untuk masuk ke dalam daftar World Heritage dan berkali-kali pula gagal atau ditolak, karena berbagai alasan, hingga detik tulisan ini dibuat.

Sosialisasi program promosi Kota Lama semarang untuk masuk menjadi salah satu daftar World Heritage Site, nampaknya baru dipahami sebagai wacana oleh lingkungan elit, akademisi, birokrat terkait, dan stake holder langsung.

Dari hasil penelusuran, tidak banyak masyarakat awam yang memahami apa itu World Heritage/ Pusaka Dunia, apalagi manfaatnya. Seyogyanya, sejak dini, informasi mengenai upaya menuju status World Heritage ini hendaknya diperkenalkan kepada masyarakat, khususnya warga Kota Semarang yang nantinya (bila perjalanannya mulus) akan mempunyai suatu kawasan yang diakui dunia sebagai obyek bersejarah.

Salah satu contoh warisan Pusaka Dunia yang terletak tidak jauh dari Kota Semarang adalah Candi Borobudur dan Candi Prambanan. Setelah masuk ke dalam daftar Pusaka Dunia, UNESCO bekerjasama dengan Pemerintah Republik Indonesia melakukan restorasi besar-besaran untuk mengembalikan kondisi candi Borobudur dan Pramabanan ke puncak kejayaannya, dan memperkenalkannya sebagai milik bersama dunia. Kunjungan pariwisata pun meningkat signifikan pasca restorasi candi-candi tersebut.
Saat ini, hanya ada 8 lokasi di Indonesia yang masuk ke dalam Daftar Pusaka Dunia. Selain Candi Borobudur dan Prambanan yang merupakan dua warisan budaya berbentuk bangunan, 6 obyek lainnya adalah: (1) Taman Nasional Ujung Kulon, (2) Sistem Subak di Bali, (3) Situs Sangiran, (4) Taman Nasional Komodo, (5) Taman Nasional Lorentz di Papua, dan (6) Taman Hujan Tropis di Sumatera yang meliputi Taman Nasional Gunung Leuser, Taman Nasional Kerinci, dan Taman Nasional Bukit Barisan (UNITAR, 2012).

Bila Kota Lama Semarang dan Kota Tua Jakarta, yang cukup berpotensi masuk ke dalam daftar World Heritage UNESCO, berhasil ditetapkan dalam Konvensi WHC, maka mereka akan menjadi 10 besar Pusaka Dunia yang terletak di Indonesia.

Contoh kawasan bersejarah peninggalan jaman kolonial yang terlebih dahulu masuk ke dalam daftar World Heritage adalah George Town di Penang dan Kota Tua Melaka, di Malaysia.

George Town dan Melaka pernah mengalami kondisi yang hampir sama dengan Kota Lama Semarang, yang hampir saja punah dan menurun kualitas fisik dan lingkungannya.

Setelah ditetapkan menjadi Pusaka Dunia oleh WHC UNESCO, kini kedua obyek wisata kawasan bersejarah di Malaysia tersebut dikunjungi oleh jutaan turis dalam dan luar negeri setiap tahunnya, terlepas dari dinamika sosial yang terjadi terkait kejutan-budaya akibat perubahan mendadak kawasan yang awalnya begitu sepi dan kemudian menjadi pusat destinasi wisata sejarah di Malaysia.

Tentunya upaya-upaya ekstra harus dilakukan oleh pemerintah pusat dan daerah, dengan disertai oleh dukungan dari semua pemangku kepentingan dan masyarakat Kota Semarang, untuk mensukseskan masuknya Kota Lama Semarang dalam daftar Pusaka Dunia oleh UNESCO.

Menurut situs resmi WHC UNESCO, saat ini Kota Lama Semarang memang sudah masuk ke dalam Tentative List World Heritage (Daftar Tentatif Pusaka Dunia), untuk selanjutnya akan dievaluasi dan dinilai kelayakannya untuk dijadikan Pusaka Dunia pada 2020.

Menurut buku Panduan Operasional Untuk Implementasi Konvensi Pusaka Dunia (Operational Guidelines for Implementation of World Heritage Convention, 2012), untuk dapat didaftarkan menjadi Pusaka Dunia, suatu situs budaya harus memenuhi beberapa kriteria, antara lain: (1) Melambangkan mahakarya kreativitas dan kecerdasan manusia serta nilai yang berpengaruh secara signifikan terhadap budaya, (2) Menunjukkan keutamaan pada nilai-nilai kemanusiaan yang tidak berubah selama kurun waktu tertentu dalam hal arsitektur, teknologi, seni monumental, perencanaan tata kota atau desain lanskap, (3) Mengandung kekhasan atau bukti bahwa pernah ada 
ritual peradaban pada masa lampau yang tersisa atau telah lenyap, (4) Wujud mengagumkan pada sebuah bangunan, arsitektur atau teknologi yang memiliki penggambaran tentang tahapan penting dalam sejarah peradaban manusia, (5) Wujud mengagumkan pada sebuah tempat tinggal, tanah, atau perairan yang dapat melambangkan budaya atau interaksi manusia dengan lingkungan, khususnya yang masih terpelihara terhadap perubahan zaman yang signifikan, dan (5) Memiliki kaitan yang erat pada suatu peristiwa atau tradisi tertentu, dari sisi pemikiran, kepercayaan, artistik dan sastra.

\section{Konklusi}

Semakin lengkap kriteria yang dimiliki suatu situs budaya, akan semakin besar peluangnya untuk dapat ditetapkan sebagai World Heritage. Saat ini, proposal pengajuan Kota Lama Semarang menjadi Pusaka Dunia hanya menyebutkan 2 kriteria saja, yaitu kriteria ke 2 (Criterion ii) bahwa Semarang mewakili contoh istimewa Kota Perdagangan multi-kultural di Asia Tenggara, yang terbentuk dari aktifitas perdagangan kekuatan pemerintah Kolonial Belanda, Jawa, Melayu, Cina, dan Arab, selama hampir 350 tahun, yang masing-masingnya meninggalkan jejak sejarah berupa karya arsitektur, bentuk kota, dan teknologi, yang merupakan titik silang nilai-nilai kemanusiaan di Asia pada awal abad 19.

Kriteria lainnya yang diajukan dalam proposal adalah Kriteria ke-4 (Criterion iv), yaitu bahwa Kota Lama Semarang mencerminkan campuran pengaruh kebudayaan, yang menciptakan karya arsitektur, budaya, dan wajah kota yang unik, yang tidak ada duanya yang sejenis di manapun di Asia Tenggara. Secara khusus, hal-hal tersebut mendemonstrasikan jenis-jenis peruntukan bangunan yang beragam dan istimewa, mulai dari bangunan kantor, pergudangan, permukiman, dan komersial lainnya. Bangunanbangunan yang ada juga memperlihatkan berbagai jenis tipe dan tahapan era pembangunan, seperti Medieval, Baroque, Indische/Indis, dan Kolonial Modern. Kota Semarang dan Stasiun Tawang di sekitar Kompleks Kota Lama Semarang juga menunjukkan keutamaan dalam sejarah teknologi transportasi dan perkereta apian pertama di Asia Tenggara, dengan hadirnya teknologi Kereta Api dan Lokomotif Uap, beserta seluruh infrastrukturnya.

Kota Lama Semarang dengan segala keunikannya merupakan Living Heritage (Pusaka Hidup), di mana aktifitas kehidupan sosial, ekonomi, dan budaya terjadi setiap hari. Bukan sekedar monumen mati (dead monument) yang tinggal dipugar atau direstorasi.

Sebagai kawasan yang hidup, dan sudah memiliki ekosistem perkotaan (urban ecosystem) tersendiri, perlakuan dan pendekatan sosial, ekonomi, dan budaya harus menjadi fokus utama dalam menata kawasan bersejarah ini.

\section{Daftar Referensi}

Bekker, J. G., Craig, I. K., \& Pistorius, P. C. (1999). Modeling and Simulation of Arc Furnace Process. ISIJ International, 39(1), 23-32.

BAPPEDA (2011) Grand Desain Kota Lama Semarang, Laporan Akhir, Pemerintah Kota Semarang, Semarang

Hendro, Eko Punto (2015) Pelestarian Kawasan Konservasi di Kota Semarang, Jurnal Konservasi Cagar Budaya Borobudur, 9(1), 17-28

Pemerintah Republik Indonesia (1992) UU. No 5 tahun 1992 tentang Benda Cagar Budaya

Pemerintah Republik Indonesia (2010) UU. No 11 tahun 2010 tentang Cagar Budaya.

Grahadwiswara, Agastya, et al. (2014) Pengelolaan Kawasan Kota Lama Semarang Sebagai Salah Satu Kawasan Pariwisata di Kota Semarang, Journal of Public Policy and Management Review, 3(4)

UNITAR (2012) Management and Conservation of World Heritage Sites 2012 Session, United Nations Institute for Training and Research, Hiroshima

World Heritage Center WHC (2014) Operational Guidelines for Implementation of World Heritage Convention, UNESCO, 2012 